\title{
HANDEL LUDŹMI JAKO CZARNA STREFA EKONOMII W PROCESIE MIGRACJI
}

Problematyka migracji od dawna interesowała geografów ludności. Od najdawniejszych czasów zjawisko migracji wywołuje daleko idące następstwa polityczne, społeczne i ekonomiczne. ${ }^{1}$ Migracje należą do najbardziej charakterystycznych zjawisk współczesnych dziejów świata. ${ }^{2}$ Migracja i mobilność są symbolem naszych czasów. Rzutują na wszystkie dziedziny życia człowieka: pracę i czas wolny. Absorbują polityków. Są przedmiotem badań naukowych. Migracja stała się istotnym czynnikiem gospodarczym. ${ }^{3}$

Procesem migracji są objęci nie tylko uchodźcy polityczni, ofiary klęsk naturalnych czy ludzie poszukujący pracy. Wśród osób, które nazywamy migrantami, można znaleźć również takie, które wbrew swojej woli zostały zmuszone do zmiany miejsca przebywania i stały się przedmiotem handlu żywym towarem ${ }^{4}$.

Migracji towarzyszą również negatywne zjawiska życia społecznego. Migranci, którzy osiedlili się w miejscu, którego do końca nie znają, stają się często ich ofiarami. W poczet negatywnych zjawisk, które towarzyszą procesom migracji, można zaliczyć min. handel ludźmi w celu świadczenia usług seksualnych oraz pracy niewolniczej, nielegalną adopcję, handel ludzkimi organami. W chwili obecnej uważa się, że handel ludźmi jest trzecim, po handlu narkotykami i bronią, nielegalnym źródłem dochodu międzynarodowych grup przestępczych. ${ }^{5}$

Niewolnictwo, handel ludźmi to synonimy pochodzące $z$ odległych epok. Współcześnie jest to wielki biznes, z którego czerpią zyski międzynarodowe, zorganizowane grupy przestępcze. Proceder ten na trwałe wpisał się w zjawisko migracji ludności. Stanowi czarną stronę procesu przemieszczania się ludzi.

\footnotetext{
M. Latuch, Demografia społeczno-gospodarcza, Warszawa 1985, s. 308.

A. Sakson, Nowa fala migracji w Europie, „Przegląd Zachodni” 1995, nr 1, s. 75

U. Köppel, Kościół przed wyzwaniem migracji, „Communio” 2000, nr 3, s. 105

Termin „handel żywym towarem” posiada negatywne znaczenie z punktu etycznego. Zob. E. Zielińska, Zwalczanie handlu ludźmi i wykorzystywania seksualnego dzieci, (w:) Prawo Wspólnot Europejskich a prawo polskie. T. 3. Dokumenty karne, red. E. Zielińska, Warszawa 2000, s. 351.

5 K. Laskowska, Handel ludźmi jako problem prawny kryminologiczny, „Wojskowy Przegląd Prawniczy” 2004, nr 2, s. 37 .
} 
Przemiany społeczno gospodarcze, jakie miały miejsce w Europie ŚrodkowoWschodniej w latach dziewięćdziesiątych ubiegłego wieku oraz wejście niẹktórych państw tego regionu w skład Unii Europejskiej, spowodowały, że proces migracji w obrębie tych państw nabrał innego charakteru. Traktaty będące fundamentem Unii Europejskiej zagwarantowały swobodny przepływ osób w ramach Wspólnoty. ${ }^{6}$ $\mathrm{Z}$ jednej strony traktaty te ułatwiły poruszanie się obywateli Unii w obrębie jej terytorium. Natomiast z drugiej dały swobodę działania międzynarodowym grupom przestępczym, które wykorzystując proces likwidacji granic między państwami członkami Unii Europejskiej, czerpią ogromne zyski z handlu żywym towarem.

Osoby trudniące się do tej pory nielegalnym handlem bronią, przemytem materiałów radioaktywnych oraz narkotyków niejednokrotnie decydują się na zmianę swojej przestępczej specjalizacji i podejmują się handlu ludźmi. Wynika to, z jednej strony, z potencjalnie mniejszych szans bycia pociągniętym do odpowiedzialności i ryzyka otrzymania relatywnie niższych kar pozbawienia wolności, z drugiej zaś z powodu wysokiej opłacalności finansowej i niewielkich kosztów własnych prowadzonej działalności. Różne statystyki podają że rocznie na całym świecie sprzedawanych jest od 700000 do 2000000 ludzi, przy czym większość stanowią kobiety ${ }^{7}$ i dzieci. Świadczy to, że nie ma się już do czynienia z wydarzeniami o charakterze epizodycznym, lecz ze świetnie zorganizowanym systemem międzynarodowej współpracy przestępców, mającym negatywny wpływ z socjologicznego, demograficznego, ekonomicznego i politycznego punktu widzenia na sytuację społeczeństw krajów uwikłanych w handel ludźmi. ${ }^{8}$ Handel ten przynosi ok. 13 miliardów dolarów zysku rocznie międzynarodowym grupom przestępczym. ${ }^{9}$

Dokładne określenie liczby osób, które stały się ofiarami handlu, nie jest możliwe. Dane, które podają różne organizacje czy instytucje, są szacunkowe, nie odzwierciedlają rzeczywistego stanu. Przyczyny są różne. Najważniejsza jednak jest ta, że o zaistnieniu przypadku handlu wiedzą sprawcy i ofiary, te zaś, będąc niekiedy jedynymi świadkami przestępstwa, z powodu niewiedzy, wstydu czy strachu, nie podejmują dalszych działań w celu ujawnienia sprawców. W związku z tym określenie rozmiarów zjawiska jest tak trudne. Szacunkowe dane Międzynarodowej Organizacji ds. Migracji z 2000 r. wskazują że rocznie około 10000 Polek pada ofiarami handlu kobietami. Statystyki policyjne natomiast, w oparciu o zgłoszone przypadki, podają liczbę około 100 kobiet rocznie będących przedmiotem handlu rocznie. ${ }^{10}$

Traktat z Maastricht, OJ C 191, 29.07.1992; Traktat Amsterdamski, OJ 340 C 27.11.1997; Traktat Nicejski, OJ C 80, 10.03.2001; czytaj również Traktat o Unii Europejskiej - komentarz, red. K. Lankosz, Warszawa 2003; S. Hambura, M. Makuszyński, Traktat ustanawiający Wspólnotę Europejską z komentarzem, Bielsko-Biała 2002.

7 M. Kołątaj, G. Sadowski, 27 milionów niewolników, „Wprost” 2002, nr 25.

8 Por. F. Jasiński, K. Krasznicki, Walka z handlem ludźmi z perspektywy Unii Europejskiej, „Państwo i Prawo” 2003 , z. 8, s. 85

9 A. Staszewska, La Strada. Handel Ludźmi w czasach demokracji, „Niebieska Linia” 2002, nr 5. 
Handel ludźmi nie jest zjawiskiem nowym. Niewolnictwa przetrwało od starożytności do czasów współczesnych. ${ }^{11}$ Zaczęto je postrzegać jako problem o zasięgu szerszym niż lokalny pod koniec XIX wieku. W 1899 r. w Londynie odbył się pierwszy międzynarodowy kongres w sprawie handlu białymi niewolnikami. Wówczas społeczność międzynarodowa podjęła współpracę w przeciwdziałaniu temu zjawisku. ${ }^{12}$ Aktualnie proceder ten zaliczany jest do grupy przestępstw międzynarodowych (konwencyjnych), podlegających ściganiu i karaniu ich sprawców przez poszczególne państwa. ${ }^{13}$

Wiele międzynarodowych traktatów uwzględniało naruszania praw człowieka w kontekście handlu ludźmi. Wśród nich można wymienić: Międzynarodowe Porozumienie z 18.05.1904 r. i Międzynarodową Konwencję z 04.05.1910 r. o zwalczaniu handlu żywym towarem ${ }^{14}$, Konwencję z 11.09.1921 r. o zwalczaniu handlu kobietami i dziećmi ${ }^{15}$, Protokół o zapobieganiu, zwalczaniu oraz karaniu za handel ludźmi w szczególności kobietami i dziećmi, uzupełniający Konwencję Organizacji Narodów Zjednoczonych przeciwko międzynarodowej przestępczości zorganizowanej przyjęty przez Zgromadzenie Ogólne ONZ 15.11.2000 r. ${ }^{16}$, Decyzję Ramową Rady Unii Europejskiej (2002/629/JHA) z 19.07.2002 r. w sprawie zwalczania handlu ludźmi ${ }^{17}$.

Konwencja w sprawie zwalczania handlu ludźmi i eksploatacji prostytucji z 1949 r. skonsolidowała wcześniejsze traktaty ${ }^{18}$ dotyczące handlu ludźmi i wykorzystywania prostytucji innych osób. Traktat ten był krytykowany m.in. za brak definicji handlu ludźmi, brak mechanizmów egzekwowania oraz za zawężenie pojęcia handlu ludźmi do przepływu ludzi między granicami w celu uprawiania prostytucji. ${ }^{19}$

Brak precyzyjnej definicji handlu ludźmi spowodował, że wiele organiza-

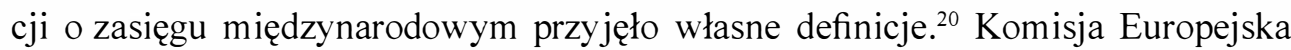
w Komunikacje z 1996 r. w sprawie handlu kobietami w celu wykorzystywania seksualnego przyjęła następującą definicję tego zjawiska:

Por. Handel ludźmi. Informacja o zjawisku 2004, red. I. Dawid-Olczyk, Anna Dośpiał. Wyd. Noktus 2004, s. 4. Na temat niewolnictwa w Europie Środkowo-wschodniej w średniowieczu zob. S. Zając, Niewolniczy rozdział, „Nowe Państwo" 2002, nr 10, s. 36-38.

J. Bryk, Handel ludźmi, „Policja” 997 2006, nr 12 (21) s. 44.

Handel ludźmi. Informacja o zjawisku 2004, red. I. Dawid-Olczyk, Anna Dośpiał, Łódź 2004, s. 4.

Dz.U. z 1922 r. Nr 87, poz. 783

Dz.U. z 1925 r. Nr 125, poz. 893

Dz.U. z 2005 r. Nr 18, poz. 160.

Dz.Urz. WE L 203 z 01.08.2002 r.

Międzynarodowe Porozumienie z 18.05.1904 r. i Międzynarodowa Konwencja z 04.05.1910 r. o zwalczaniu handlu żywym towarem, Konwencja z 11.09.1921 r. o zwalczaniu handlu kobietami i dziećmi, Międzynarodowa Konwencja z 30.09.1933 r. w sprawie zniesienia handlu pełnoletnimi kobietami.

E. Pearson, Handel ludźmi a prawa człowieka. Nowe rozumienie ochrony ofiar, Warszawa 2002, s. 12-13.

F. Jasiński, K. Krasznicki, Walka z handlem ludźmi z perspektywy Unii Europejskiej, „Państwo i Prawo” 2003,

z. 8, s. 84 . 
„Handel ludźmi w celu wykorzystywania seksualnego obejmuje kobiety, wobec których stosowano zastraszanie, przemoc poprzez handel. Wstępna zgoda może nie być istotna, gdyż niektóre kobiety stają się elementem łańcucha handlu, wiedząc, że będą pracowały jako prostytutki, ale później są pozbawiane przysługujących im podstawowych praw człowieka, w warunkach, które są podobne do niewolnictwa". Późniejszy Komunikat Komisji Europejskiej z 12.1998 r. sugeruje, że definicja powinna być rozszerzona i ,uwzględniać także kobiety, które są nielegalnie przewożone za granicę i zmuszane do wykonywania innych form skomercjalizowanego seksu, jak również kobiety, które zostały zmuszone do zawarcia związku małżeńskiego w celu komercyjnego wykorzystywania seksualnego".

Według Międzynarodowej Organizacji ds. Migracji do handlu ludźmi dochodzi, gdy: migrant zostaje bezprawnie zaangażowany (zwerbowany, porwany, sprzedany itp.) i/lub jest przewożony w kraju lub przez międzynarodowe granice, a pośrednicy (handlarze) w dowolnej części tego procesu uzyskują ekonomiczny lub inny dochód poprzez oszukiwanie, zmuszanie lub inne formy wykorzystywania w warunkach, które naruszają podstawowe prawa imigrantów. ${ }^{21}$

Z punktu widzenia praktyki najważniejszym traktatem międzynarodowym dotyczącym handlu ludźmi jest Konwencja Narodów Zjednoczonych przeciwko międzynarodowej przestępczości zorganizowanej z 2000 roku wraz z Protokołem uzupełniającym zapobieganiu, zwalczaniu oraz karaniu za handel ludźmi, w szczególności kobietami i dziećmi. Przepis artykułu 3 ww. Protokołu definiuje pojęcie handlu ludźmi jako werbowanie, transport, przekazywanie, przechowywanie lub przyjmowanie osób, z zastosowaniem groźby lub użyciem siły, lub też z wykorzystaniem innej formy przymusu, uprowadzenia, oszustwa wprowadzania w błąd, nadużycia władzy lub wykorzystania słabości, wręczenia lub przyjęcia płatności, lub korzyści dla uzyskania zgody osoby mającej kontrolę nad inną osobą, w celu wykorzystania. Wykorzystanie obejmuje wykorzystanie prostytucji innych osób lub inne formy wykorzystania seksualnego, pracę lub usługi o charakterze przymusowym, niewolnictwo lub praktyki podobne do niewolnictwa, zniewolenie albo usunięcie organów. ${ }^{22}$

21 E. Pearson, Handel ludźmi a prawa człowieka. Nowe rozumienie ochrony ofiar, Warszawa 2002, s. 12-13. 
Statystyki - Nielegalny handel i eksploatacja ludzi w Polsce ${ }^{23}$

\begin{tabular}{||c|c|c|c|c|c|c||}
\hline \multirow{2}{*}{ Rok } & \multicolumn{2}{|c|}{ Art. 204 par. 4 } & \multicolumn{2}{c|}{ Art. 253 par. 1 } & \multicolumn{2}{c|}{ Art. 253 par. 2 } \\
\cline { 2 - 7 } & $\begin{array}{c}\text { Liczba } \\
\text { przestępstw }\end{array}$ & $\begin{array}{c}\text { Liczba } \\
\text { podejrzanych }\end{array}$ & $\begin{array}{c}\text { Liczba } \\
\text { przestępstw }\end{array}$ & $\begin{array}{c}\text { Liczba } \\
\text { podejrzanych }\end{array}$ & $\begin{array}{c}\text { Liczba } \\
\text { przestępstw }\end{array}$ & $\begin{array}{c}\text { Liczba } \\
\text { podejrzanych }\end{array}$ \\
\hline 1999 & 3 & 4 & 5 & 3 & 3 & 3 \\
\hline 2000 & 6 & 7 & 19 & 12 & 0 & 0 \\
\hline 2001 & 10 & 3 & 24 & 23 & 1 & 0 \\
\hline 2003 & 2 & 2 & 8 & 7 & 0 & 0 \\
\hline 2004 & 6 & 1 & 21 & 21 & 0 & 0 \\
\hline 2005 & 3 & 4 & 19 & 9 & 1 & 1 \\
\hline
\end{tabular}

W polskim systemie prawnym przepisy penalizujące handel ludźmi znajdują się w Kodeksie karnym ${ }^{24}$. W artykule 253 została określona odpowiedzialność za przestępstwo handlu ludźmi, zwane również przestępstwem handlu żywym towarem. ${ }^{25}$ Należy jednak zauważyć, że przepis artykułu $253 \S 1$ kk. posługuje się niezdefiniowanym pojęciem ,handlu ludźmi”, które wywołuje zarówno w judykaturze, jak i te-

23 Statystyka Komendy Głównej Policji.

24 Ustawa z dnia 06.06.1997 r. Kodeks karny Dz.U. Nr 88, poz. 553. Zob. art. 189. § 1. Kto pozbawia człowieka wolności, podlega karze pozbawienia wolności od 3 miesięcy do lat 5. § 2. Jeżeli pozbawienie wolności trwało dłużej niż 7 dni lub łączyło się ze szczególnym udręczeniem, sprawca podlega karze pozbawienia wolności od roku do lat 10. Art. 190. §1. Kto grozi innej osobie popełnieniem przestępstwa na jej szkodę lub szkodę osoby najbliższej, jeżeli groźba wzbudza w zagrożonym uzasadnioną obawę, że będzie spełniona, podlega grzywnie, karze ograniczenia wolności albo pozbawienia wolności do lat 2. § 2. Ściganie następuje na wniosek pokrzywdzonego. Art. 191. § 1. Kto stosuje przemoc wobec osoby lub groźbę bezprawną w celu zmuszenia innej osoby do określonego działania, zaniechania lub znoszenia, podlega karze pozbawienia wolności do lat 3. § 2. Jeżeli sprawca działa w sposób określony w $\S 1$ w celu wymuszenia zwrotu wierzytelności, podlega karze pozbawienia wolności od 3 miesięcy do lat 5. Art. 197. § 1. Kto przemocą, groźbą bezprawną lub podstępem doprowadza inną osobę do obcowania płciowego, podlega karze pozbawienia wolności od roku do lat 10 . § 2 . Jeżeli sprawca, w sposób określony w $\S 1$, doprowadza inną osobę do poddania się innej czynności seksualnej albo wykonania takiej czynności, podlega karze pozbawienia wolności od 3 miesięcy do lat 5. § 3. Jeżeli sprawca dopuszcza się zgwałcenia określonego w § 1 lub 2, działajac ze szczególnym okrucieństwem lub wspólnie z inna osoba, podlega karze pozbawienia wolności od lat 2 do 12. Art. 203. Kto, przemoca, groźbą bezprawna, podstępem lub wykorzystując stosunek zależności lub krytyczne położenie, doprowadza inną osobę do uprawiania prostytucji, podlega karze pozbawienia wolności od roku do lat 10. Art. 204. §1. Kto, w celu osiągnięcia korzyści majątkowej, nakłania inna osobę do uprawiania prostytucji lub jej to ułatwia, podlega karze pozbawienia wolności do lat 3. $\S 2$. Karze określonej w $\S 1$ podlega, kto czerpie korzyści majątkowe $z$ uprawiania prostytucji przez inną osobę. $\S 3$. Jeżeli osoba określona w $\S 1$ lub 2 jest małoletnim, sprawca podlega karze pozbawienia wolności od roku do lat 10. § 4. Karze określonej w § 3 podlega, kto zwabia lub uprowadza inną osobę w celu uprawiania prostytucji za granica. Art. 253. § 1. Kto uprawia handel ludźmi nawet za ich zgoda, podlega karze pozbawienia wolności na czas nie krótszy od lat 3. § 2. Kto, w celu osiągnięcia korzyści majątkowej, zajmuje się organizowaniem adopcji dzieci wbrew przepisom ustawy, podlega karze pozbawienia wolności od 3 miesięcy do lat 5.

25 Swoistą interpretację tego artykułu podał Sąd Apelacyjny w Lublinie, który wyroku orzekł, że „[...] jednostkowa transakcja sprzedaży człowieka czy nawet ludzi, zgodnie z przeważającymi w judykaturze i doktrynie poglądami nie może być w żadnym wypadku uznana za uprawianie handlu ludźmi w rozumieniu art. $253 \S 1$ kk." Patrz szerzej wyrok Sądu Apelacyjnego w Lublinie, Ka 270/01, „Prokuratura i Prawo” 2003, nr 4. 
orii prawa karnego wiele wątpliwości. ${ }^{26}$ Kontrowersje te pojawiły się już na etapie projektowania treści zapisów Kodeksu karnego z 1997 r. Artykuł 253 § kk. uznany został za sprzeczny z zasada jasności i zrozumiałego formułowania przepisu karnego. ${ }^{27}$ Wątpliwości budzi termin ,handel” oraz interpretacja słowa ,ludzie”. ${ }^{28}$

Karalność tego przestępstwa wynika z ratyfikowanych przez Polskę konwencji międzynarodowych, zakazujących niewolnictwa. Odpowiedzialności z artykułu 253 podlega handel, czyli taki czyn, gdy sprawca traktuje człowieka jako przedmiot transakcji cywilnoprawnej. Handel jest obrotem towarowo-pieniężnym, zatem handel ludźmi wyraża traktowanie człowieka jako towaru, a więc bezpodmiotowość istoty ludzkiej jako jego przedmiotu. ${ }^{29}$ Handel ludźmi traktowany jest jako przestępstwo powszechne. Sprawcą przestępstwa może być każdy, kto w jakikolwiek sposób bierze udział w tym swoistym obrocie handlowym, zarówno sprawca, nabywający, jak i pośrednicy biorący udział w transakcji. Dla zaistnienia przestępstwa nie ma znaczenia cel, w jakim dokonuje się sprzedaży. Sprawca ponosi taką samą odpowiedzialność karną bez względu na cel transakcji.

Głównymi przyczynami istnienia handlu ludźmi są m.in. bieda, bezrobocie, niski poziom edukacji i niewystarczający dostęp do źródeł pomocy w tzw. krajach pochodzenia (głównie z Europy Środkowej i Wschodniej, byłych republik ZSRR, krajów Afryki i Dalekiego Wschodu), a także możliwość zdobycia tanich i nieewidencjonowanych pracowników przez pracodawców z wysoko rozwiniętych tzw. państw docelowych (krajów Europy Zachodniej i USA). Ponadto z handlem ludźmi powiązany jest ich przemyt ${ }^{30}$. Różnicą między tym zjawiskiem jest to, że w pierwszym przypadku ofiary nie wiedzą lub nie zdają sobie sprawy z sytuacji, w której się znalazły - często są przekonane, że wyjeżdżając za granicę, będą zajmować się np. intratną opieką nad dziećmi lub sezonowymi pracami polowymi. Odnośnie do prze-

Zob.: wyrok SA w Krakowie z dnia 08.03.2000 r., ॥ AKa 71/2000, KZS 2000, nr 6, poz. 14; wyrok SN z dnia 07.06.2001 r., V KKN 109/99, OSNKW 2001, nr 9-10, poz. 79; wyrok SN z dnia 19.04.2002 r., V KKN 353/00, „Prokuratura i Prawo” 2002, dodatek Orzecznictwo, nr 11, poz. 4; wyrok SA we Wrocławiu z dnia 21.02.2003 r., ॥ AKa586/02, OSA 2003, nr 5, poz. 405; wyrok SA w Białymstoku z dnia 24.05.2004 r., II AKa66/04, OSAB 2004 nr 3, poz. 30; A. Marek, Kodeks karny. Komentarz, Warszawa 2004, s. 533; E. Pływaczewski, (w:) A. Wa sek (red.), Kodeks karny Część szczególna, t. II. Komentarz do artykułów 222-316, Warszawa 2005, s. 372; K. Laskowska, Handel ludźmi jako problem prawny i kryminologiczny, "Wojskowy Przegląd Prawniczy” 2004, nr 2, s. 29-39, K. Krasznicki, Handel kobietami w świetle spraw karnych, „Prokuratura i Prawo” 2002, nr 12, s. 67; J. Warylewski, Karalność handlu żywym towarem w świetle nowego kodeksu karnego, „Palestra” 2000, nr 7-8, S. $43-56$

Zob. L. Gardocki, Organizowanie adopcji a handel dziećmi, „Palestra” 1994, nr 11; M. Filar, Glosa do uchwały z 29.09.1995, I KZP 33/95, „Państwo i Prawo” 1996, nr 12.

Zob. A. Marek, Prawo karne, Warszawa 2005, s. 653; Z. Ćwiakalski, (w:) Kodeks karny, Część szczególna. Komentarz, t. II, Kraków 1999, s. 896; wyrok SA w Białymstoku z dnia 24.05.2004 r., II AKa 66/04, OSAB 2004, nr 3, poz. 30; wyrok SN z dnia 19.04.2002 r., V KKN 353/00, Lex nr 56863 
mytu zainteresowane osoby świadomie akceptują ten fakt i opłacają swój transport do innego kraju (sprawcy ułatwiają wówczas nielegalne przekraczanie granicy). ${ }^{31}$

Istnieje wiele form stosowanych praktyk wyzysku powiązanych $\mathrm{z}$ handlem ludźmi. ${ }^{32}$ Do tych form można zaliczyć:

1. Handel ludźmi w celu świadczenia usług seksualnych. Proceder ten związany jest z przymuszaniem do pracy w seksbiznesie, tj. do prostytucji i pornografii. Zjawisko to obejmuje nabór osób, przetrzymywanie, przewożenie i zmuszanie do świadczenia usług seksualnych. Jest to najbardziej rozpowszechniona i znana forma handlu ludźmi.

2. Handel ludźmi związany z przymusową pracą ${ }^{33}$. Od zjawiska tego należy odróżnić migrację zarobkową i nielegalną pracę. W procederze tym można wyróżnić następujące formy:

- praca za długi jest najprawdopodobniej najmniej znaną dzisiaj formą handlu ludźmi, a przecież najszerzej stosowaną formą zniewolenia. Ofiary tego procederu stają się tak zwanymi pracownikami ,za długi” w momencie, gdy ich praca jest formą spłaty pożyczki, której zasady nie zostały sprecyzowane. Wartość tej pracy jest większa niż pierwotnie zaciągnięta kwota pożyczki;

- praca przymusowa ma miejsce wówczas, gdy ofiara tego procederu jest zmuszana do pracy wbrew własnej woli pod groźba przemocy lub innej formy kary. Wolność takiej osoby jest ograniczona. Formy pracy przymusowej obejmują pracę w charakterze pomocy domowej, pracę w rolnictwie, rybołówstwie, ciężką pracę fizyczną w fabrykach, prostytucję, stróżowanie i ochronę budynków, pracę w branży gastronomicznej i żebractwo;

- praca dzieci to praca, która może stanowić zagrożenie dla zdrowia fizycznego, psychicznego, duchowego oraz rozwoju moralnego i społecznego dzie-

Por. F. Jasiński, K. Krasznicki, Walka z handlem ludźmi z perspektywy Unii Europejskiej, „Państwo i Prawo” 2003, z. 8, s. 85.

Według danych statystycznych Międzynarodowej Organizacji Pracy $80 \%$ ofiar handlu ludźmi to kobiety i dziewczęta, od $40 \%$ do $50 \%$ ofiar to dzieci. Kobiety stanowią $56 \%$ ofiar pracy przymusowej, a spośród osób sprzedawanych w celach seksualnych $98 \%$.

33 Obecnie mamy do czynienia $z$ handlem ludźmi w formie pracy niewolniczej. Obozy pracy na południu Włoch oraz w Hiszpanii są tego charakterystycznym przykładem. Pojawiają się w nich wątki międzynarodowej organizacji przestępczej działajacej zarówno w Polsce, jak i poza granicami. W ramach polsko-włoskiej operacji „Ziemia Obiecana", rozbito międzynarodową organizację przestępczą składającą się z obywateli Polski, Ukrainy, Włoch i Algierii. Organizacja stworzyła na terenie włoskiej prowincji Apulia niewolnicze obozy pracy, w których przetrzymywani byli obywatele polscy. Zwabiono ich podstępnie do Włoch obietnicą zatrudnienia i osiagnięcia wysokich zarobków. Ofiary były werbowane na terenie Polski i transportowane do obozów pracy, a następnie pozbawiane pieniędzy, mienia oraz wykorzystywane do pracy niewolniczej w warunkach uragających ludzkiej godności. Stosowano wobec nich przemoc fizyczna, torturowano, bito, gwałcono i szczuto psami. Wśród ofiar dochodziło do samobójstw. Były także zabójstwa. Zob. (w:) J. Bryk, Handel ludźmi, „Policja 997” 2006, nr 12, s. 45. Również w Polsce mamy do czynienia z obozami pracy, o czym można przeczytać (w:) J. Urbański, Łagier Nadwiślański, „Wprost” 2007, nr 12, s. 38; Niewolnicy XXI wieku. Wykorzystywani i bici. Chińskie cegielnie, brazylijskie plantacje, „Rzeczpospolita” 2007, nr 155, s. 7. 
ci i może kolidować z ich nauką. Międzynarodowa Organizacja Pracy (ILO) szacuje liczbę pracujących dzieci w wieku od 5 do 17 lat na 246000000 na świecie. Pracują one za długi, są zmuszane do udziału w konfliktach zbrojnych, do prostytucji, pornografii i wielu innych nielegalnych form zarobkowania na całym świecie. Do prac domowych poszukiwane są szczególnie dziewczęta. ${ }^{34}$

3. Handel dziećmi w celu świadczenia usług seksualnych. Wyróżnić można tu takie zjawiska, jak nielegalna adopcja oraz sprzedaż osoby nieletniej pedofilom. ${ }^{35}$

4. Handel narządami. Jest to najmłodsza gałąź procederu, jakim jest handel żywym towarem. Powstał w wyniku rosnącego zapotrzebowania w krajach wysokouprzemysłowionych na organy ludzkie potrzebne do transplantacji oraz dużego postępu w medycynie. Nielegalny handel narządami ludzkimi przyczynia się do powstawania dodatkowych problemów etycznych w tak trudnej i złożonej moralnie dziedzinie medycyny, jaką jest transplantacja. ${ }^{36}$

Wśród grup przestępczych trudniących się procederem handlu żywym towarem występuje pewna specjalizacja. Wyróżnić można następujące typy: grupy, które ograniczają się do werbowania osób do prostytucji; grupy, które zajmują się zarówno werbunkiem, konwojem, a po przybyciu do miejsca docelowego także sprzedażą zwerbowanych wcześniej osób; grupy, które zajmują się bezpośrednią eksploatacją prostytucji, czerpiąc zyski z prowadzonych przez siebie domów publicznych; potężne zorganizowane grupy przestępcze, które kontrolują całą sieć domów publicznych, a także agencji towarzyskich; grupy specjalizujące się w pornografii, które do publikowanych przez siebie pism bądź realizowanych filmów wykorzystuja kobiety i dzieci nabyte od handlarzy ludźmi. ${ }^{37}$ Celem handlu ludźmi, tak jak przed wiekami, jest zdobywanie taniej, często darmowej i nielegalnej siły roboczej, jednak wiele sprzedawanych osób wykorzystywanych jest przede wszystkim do celów seksualnych. ${ }^{38}$

Handel ludźmi jest zagrożeniem wielowymiarowym: pozbawia ludzi przysługujących im praw i swobód, stanowi globalne zagrożenie dla życia i zdrowia,

Zob. szerzej www.acf.hhs.gov/trafficking

Szerzej na temat tego procederu Dzieci i młodzież - ofiary handlu: działania regionalne na rzecz zapewnienia im prawa do ochrony, opieki i rehabilitacji. Tł. A. Nowak., „Dziecko Krzywdzone” 200, nr 12; Badania dotyczące handlu dziećmi w Europie. Tł. A. Nowak, „Dziecko Krzywdzone” 2005, nr 12; M. Kukułowicz, Polityka Unii Europejskiej wobec problemu handlu dziećmi, „Dziecko Krzywdzone” 2005, nr 12; A. Morawska, Proceder handlu dziećmi - perspektywa doświadczeń europejskich, „Dziecko Krzywdzone” 2005, nr 12

Szerzej na temat dylematów etycznych związanych z transplantacją M. Gałuszka, Etyka a społeczne wartości transplantologii, „Żyjmy Dłużej” 1995, nr 5; J. Kopania, Niemoralny aspekt transplantacji, „W drodze” 1997, nr 1; J. Petry-Mroczkowska. Przeszczepy, wartość i cena, „W drodze” 1997, nr 1.

M. Wasilewska. Handel żywym towarem w celach prostytucji, „Dziś” 2005, nr 8, s. 182

F. Jasiński, K. Krasznicki, Walka z handlem ludźmi z perspektywy Unii Europejskiej, „Państwo i Prawo” 2003, z. 8, s. 85 
jest jedną z postaci przestępczości zorganizowanej. Wpływa nie tylko na jednostki, które padają jego ofiarami, ale także zmniejsza jakość zabezpieczenia społecznego wszystkich narodów, których dotyczy to zjawisko, zagraża bezpieczeństwu i porządkowi publicznemu. ${ }^{39}$

Ironią współczesnego świata jest fakt, że bogate państwa Zachodu z jednej strony publicznie szafują obroną praw człowieka i godności ludzkiej, a z drugiej strony są głównymi nabywcami niewolników w postaci taniej siły roboczej, usług seksualnych czy niezbędnych do transplantacji organów ludzkich. Można śmiało stwierdzić, że w szeroko pojętym handlu ludźmi działają prawa, którymi rządzi się ekonomia, tzn. popyt, podaż, zysk. Dopóki będzie zapotrzebowanie na towar, jakim są współcześni niewolnicy, dopóty migranci dobrowolni i ci z przymusu będą w kręgu zainteresowań zorganizowanych grup przestępczych. Ich niestabilna sytuacja życiowa sprawia, że stają się łatwymi ofiarami handlu ludźmi. 


\section{HANDEL LUDŹMI JAKO CZARNA STREFA EKONOMII W PROCESIE MIGRACJI}

Problematyka migracji od dawna interesowała geografów ludności. Od najdawniejszych czasów zjawisko migracji wywołuje daleko idące następstwa polityczne, społeczne i ekonomiczne, a migracje należą do najbardziej charakterystycznych zjawisk współczesnych dziejów świata. Zjawisko to, jakże charakterystyczne dla współczesności, powiązane jest w nierozerwalny sposób z handlem ludźmi. Istnieje również wiele form stosowanych praktyk wyzysku powiązanych z handlem ludźmi.

Handel ludźmi jest zagrożeniem wielowymiarowym: pozbawia ludzi przysługujących im praw i swobód, stanowi globalne zagrożenie dla życia i zdrowia, jest jedną z postaci przestępczości zorganizowanej. Wpływa nie tylko na jednostki, które padają jego ofiarami, ale także zmniejsza jakość zabezpieczenia społecznego wszystkich narodów, których dotyczy to zjawisko, zagraża bezpieczeństwu i porządkowi publicznemu. 


\section{TRAFFICKING IN HUMAN BEINGS AS THE BLACK ZONE OF ECONOMICS IN THE PROCESS OF MIGRATION}

The issue of migration has been the subject matter of interest to geographers for a long time. From far back, the phenomenon of migration has had far-reaching political, social, and economic implications and migration is among the most characteristic phenomena in the modern history of the world. This phenomenon, so characteristic of present times, is unequivocally associated with the trafficking in human beings. Equally, there are many practices relating to acts of exploitation which can be directly linked to human trafficking.

Human trafficking is a multidimensional threat: it deprives people of their rights and freedoms, constitutes a global threat to life and health, and is one of the many forms of organized crime. It affects not only the individuals who are its victims, but also reduces the quality of the social security of all nations concerned and endangers both safety and public policy.

Key words: migrations, pathology, trafficking in people, victims, smuggling 